\title{
Non-flying mammals of Chapada Diamantina (Bahia, Brazil)
}

\author{
Luciana Guedes Pereira ${ }^{1} \&$ Lena Geise ${ }^{2}$ \\ ${ }^{1}$ Habtec Engenharia Sanitária e Ambiental Ltda. \\ Av. 13 de Maio no. 13 Gr. 1508, Centro, CEP 20.003-900, Rio de Janeiro, RJ, Brazil \\ ${ }^{2}$ Laboratório de Mastozoologia, Departamento de Zoologia, Instituto de Biologia, \\ Universidade do Estado do Rio de Janeiro - UERJ, \\ Rua São Francisco Xavier 524, CEP 220559-900, Rio de Janeiro, RJ, Brazil. \\ E-mail: lenageise@gmail.com \\ Corresponding author: Luciana Guedes Pereira, e-mail: luciana@gpereira.bio.br
}

PEREIRA, L.P. \& GEISE, L. Non-flying mammals of Chapada Diamantina (Bahia, Brazil). Biota Neotrop., 9(3): http://www.biotaneotropica.org.br/v9n3/en/abstract?article+bn03709032009.

\begin{abstract}
Chapada Diamantina is located in central Bahia state, and has a large diversity of habitats, including important transitional areas, but has remained largely unstudied until now. In the present study we list the nonflying mammals of Chapada Diamantina National Park and surroundings. We captured only small non-volant mammals, medium and large mammals were assessed through indirect evidences (tracks and marks) and interviews. We recorded 58 species and 47 genera from seven Mammalian orders. Seven species are included in the list of endangered Brazilian species by IBAMA and IUCN; and other seven are classified as data-deficient. Species richness of small mammals was equivalent among sampled habitats, but species composition varied among habitats (10 in semi-deciduous forest, 9 in rocky savanna and 8 in cerrado sensu stricto), as some species are restricted by humidity to forest habitats. During four different samplings, eight species were collected only in open vegetation, four only in forests, and six in both habitats. Oligoryzomys rupestris and Gracilinanus microtarsus had its geographic range expanded. Faunal composition is similar to the one observed in the Atlantic Forest, including species from Cerrado and Caatinga. Besides, some species occupy different habitats from those previously ascribed to them.
\end{abstract}

Keywords: mammal diversity, zoogeography, Cerrado, Caatinga, Atlantic Forest.

PEREIRA, L.P. \& GEISE, L. Mamíferos não-voadores da Chapada Diamantina (Bahia, Brasil). Biota Neotrop., 9(3): http://www.biotaneotropica.org.br/v9n3/en/abstract?article+bn03709032009.

Resumo: A Chapada Diamantina está localizada na parte central do Estado da Bahia, apresentando grande diversidade de habitats, assim como áreas de transição. Seu isolamento da Mata Atlântica costeira por extensa área de vegetação aberta fazem com que seja uma região de particular interesse na compreensão dos padrões de ocorrência e evolução da mastofauna neotropical. Uma lista de mamíferos não voadores do Parque Nacional da Chapada Diamantina e arredores foi elaborada. O esforço de captura foi realizado apenas para pequenos mamíferos, assim, a sua composição e riqueza de espécies entre habitats (floresta decidual, cerrado sensu stricto e campo rupestre) foram calculadas. Visitas às coleções científicas permitiram, junto com os dados de coletas, a compilação de 58 espécies e 47 gêneros de sete ordens de mamíferos. Sete espécies estão incluídas nas listas de espécies brasileiras ameaçadas de extinção do IBAMA e do IUCN; e outras sete estão classificadas como espécies com pouco conhecimento. A riqueza de espécies de pequenos mamíferos foi equivalente entre os habitats sem relação com o esforço amostral e número de espécies coletadas (10 na floresta decidual, nove em campo rupestre e oito no cerrado sentido restrito). A composição de espécies de pequenos mamíferos variou entre habitats, já que algumas espécies são restritas a ambientes úmidos e com fitosionomia florestal. Durante os quatro períodos de captura foi observada uma maior afinidade de algumas espécies em relação ao tipo de vegetação: oito ocorreram apenas em vegetação aberta, quatro apenas em floresta e seis espécies nos dois tipos de habitats. Oligoryzomys rupestris e Gracilinanus microtarsus tiveram sua distribuição geográfica expandida. A composição faunística apresenta afinidades com a Mata Atlântica com a influência do Cerrado e da Caatinga, com algumas espécies ocupando habitats diferentes daqueles previamente registrados.

Palavras-chave: diversidade de mamíferos, zoogeografia, Cerrado, Caatinga, Mata Atlântica. 


\section{Introduction}

Mammal diversity is strongly related to the history and evolution of continents (Eisenberg 1999). The present high diversity of mammals in the Neotropics is related to past climate changes mainly in the Andean region, with consequences all over South America (Reig 1986, Bush 1994, Cartelle 1999, Mortiz et al. 2000, Pardinãs et al. 2002, de Vivo \& Carmignotto 2004, Grelle et al. 2005, Carnaval et al. 2009). Mammal trapping effort in Brazil has largely been concentrated on the Amazon and Atlantic Forest (eg. Mustrangi \& Patton 1997, Patton et al. 1997, Percequillo 1998, Grelle 2000, Lara \& Patton 2000, Moritz et al. 2000, Patton et al. 2000, Bonvicino et al. 2001, Costa 2003, Patton \& Costa 2003, Gonçalves \& Oliveira 2004). There are, though, a few studies carried out in Caatinga, Cerrado and Pantanal when compared with those carried out in the Atlantic Forest (e.g. de Vivo 1997, Bonvicino \& Weksler 1998, Langguth \& Bonvicino 2002, Basile 2003, Bonvicino et al. 2003, Oliveira et al. 2003, Carmignotto, 2004, Weksler \& Bonvicino 2005).

Neotropical biomes are connected through transitional areas, for instance between the Atlantic Forest and Cerrado (Prance 1992; Eisenberg \& Redford 1999) or Caatinga (Veloso et al. 1991; Rizzini 1997). Parque Nacional da Chapada Diamantina (PNCD) is located in the centre of Bahia state $\left(11^{\circ}\right.$ and $14^{\circ} \mathrm{S}, 41^{\circ}$ and $\left.43^{\circ} \mathrm{W}\right)$, in a Y- shaped mountain range. Beside the PNCD be included in Caatinga domains, it has a wide range of habitats and altitudes, including swamp areas (locally called "marimbus"), caatinga, humid and dry forests, rocky savanna ("campo rupestre"), cerrado sensu stricto, and transitional areas (Brazão \& Araújo 1981; Parrini et al. 1999). The Brazilian workshop "Avaliação e ações prioritárias para a conservação da biodiversidade da Mata Atlântica e Campos Sulinos" (Assessment and priority actions for biodiversity conservation of Atlantic Forest and Southern Grasslands) pointed out the whole Chapada Diamantina region as one of the priority areas for biodiversity conservation (Heringer \& Montenegro, 2000).

Chapada Diamantina is considered a refuge for birds, reptiles, amphibians, mammals and the flora, with a unique faunistic formation since the Quaternary (Rodrigues-Filho et al. 2002). Those characteristics and the lack of available information (Conservation International of Brazil et al. 2000) make it an important area for research. Recently, Oliveira \& Pêssoa (2005) published a study about the mammal fauna of the Chapada Diamantina, and before that, Gregorin \& Mendes (1999) listed 11 species of bats. Bat fossils from the Pleistocene were also registered by Cartelle \& Abuhid (1994) and Czaplewski \& Cartelle (1998).

We herein present an account of non-flying mammal species of Chapada Diamantina National Park and surroundings, resultant of mammal trapping effort, museum collection and literature analysis. A report is also made on the species composition and richness of small mammals in three studied habitats (semi deciduous forest, cerrado sensu stricto and rocky savanna).

\section{Materials and Methods}

Information on mammal species and their occurrence sites in Chapada Diamantina was obtained through capture of small mammals, direct in situ observations, analysis of specimens from zoological collections (Museu Nacional do Rio de Janeiro - MN, Rio de Janeiro, Museu de Zoologia da Universidade de São Paulo - MZUSP, São Paulo and University of California Museum of Vertebrate Zoology - MVZ, Berkeley), and interviews.

The field sampling was carried out between 2002 and 2004, in different vegetation habitats (Table 1), different sampling efforts and in different year periods. Collecting licenses were obtained from IBAMA (02001.009093/02-23 and 02001.009074/02-86). Three kinds of live traps were used: Sherman $^{\odot}$ (height: $10 \mathrm{~cm}$, width: $8 \mathrm{~cm}$, depth: $30.5 \mathrm{~cm}$ ), Tomahawk ${ }^{\odot}$ (height: $15 \mathrm{~cm}$, width: $14 \mathrm{~cm}$, depth: $41 \mathrm{~cm}$ ) with bananas, manioc and peanut butter as bait and pitfall. Sherman ${ }^{\odot}$ and Tomahawk $^{\odot}$ traps were placed $15 \mathrm{~m}$ apart in lines on the ground and on trees, varying according to topography and presence of trees. Pitfalls were placed in star formations or lines only in semi-deciduous forest (Remanso and Margem do Rio Saminas), as rocky soil in other habitats did not allow digging holes.

Sampling effort differed among localities according to terrain conditions (Table 1), and a comparison was performed in those where a higher sampling effort was accomplished (more than 1,000 trap. nights) and more species (more than five species) were collected (semi-deciduous forest, cerrado sensu stricto and rocky savanna). Those vegetation types were found at six localities (Table 1). The total sampling effort measured in trap.nights was 10,897 for Sherman ${ }^{\odot}$ and Tomahawk $^{\odot}$, and 2,671 for pitfall, with a total of 13,568 trap.nights. Field work was carried out in eight localities: two in semi-deciduous forest (Remanso - 6,306 trap.nights, and Foz do Córrego do Brejão - 640 trap.nights), one in cerrado sensu stricto (savanna with trees reaching 3-8 $\mathrm{m}$ in height) (Torre da Tele-Bahia - 3,910 trap.nights), two in rocky savanna (mountain top vegetation known as;campo rupestre') (Rio Cumbuca - 720 trap.nights, and Pousada Pé-de-Serra -210 trap.nights), one in a gallery forest (riparian vegetation along streams in cerrado landscapes) (Estação de Tratamento de Água de Mucugê - 201 trap.nights), one in "cerradão" (savanna with trees reaching 8-12 m in height) (Fazendo do Zé Leandro - 360 trap.nights) and one at the border of semi-deciduous forest and rocky savanna (Rio Saminas - 1,221 trap.nights), so both habitats were sampled (Table 1). Three vegetation types were the most sampled: semi-deciduous forest with 7,712 trap.nights (57\%), cerrado sensu stricto with 3,910 trap. nights (29\%), and rocky savanna with 1,385 trap.nights (10\%).

Specimens were identified to the species level by comparison with specimens deposited in museums, and also by using morphological descriptions available for family Didelphidae (Mustrangi \& Patton 1997; Costa et al. 2003; Voss et al. 2004, 2005), subfamily Sigmodontinae (Tribe 1996, 2005; Bonvicino et al. 1999; Gonçalves et al. 2005; Weksler \& Bonvicino 2005; Weksler et al. 2006; Percequillo et al. 2008), and family Echimyidae (Lara \& Patton 2000; Bonvicino et al. 2002; Basile 2003; Corrêa et al. 2005; Pessoa et al. 2005). Medium and large mammals were identified in the field using Emmons \& Feer (1997), Eisenberg \& Redford (1999) and Reis et al. (2006). Taxonomic nomenclature follows Wilson \& Reeder (2005), as well as Bonvicino \& Moreira (2001), Bonvicino et al. (2002), Costa et al. (2003), Weksler et al. (2006), Reis et al. (2006) and Bonvicino et al. (2008). Conservation status follows Machado et al. (2008) and the IUCN Red List of Threatened Species (IUCN, 2008; http://www. iucnredlist.org/details/730/0 - July $10^{\text {th }}$, 2009). Vegetation types follow Veloso et al. (1991) and Juncá et al. (2005).

Voucher specimens (skull, skin and partial skeleton) were deposited at Museu Nacional do Rio de Janeiro (MN) and Museu de Zoologia da Universidade de São Paulo (MZUSP) (see Appendix).

\section{Results}

\section{Species account}

Fifty-eight non-flying mammal species were catalogued: 23 from field work, 17 from literature (Souza 2005; Oliveira \& Pêssoa 2005), 23 from museum records and 21 from interviews and observations, with some species included in more than one category (Table 2). A total of 316 specimens of non-flying mammals were recorded during field work (Table 3 and Figure 1), including collected (260), captured-and-released (51), road-killed specimens 
Mammals of Chapada Diamantina

Table 1. Sampling localities and their respective vegetation types. Numbers in parentheses correspond to localities plotted in Figure 1.

Tabela 1. Localidades de amostragem e seus respectivos tipos de vegetação. Números em parênteses correspondem a localidades na Figura 1.

\begin{tabular}{|c|c|c|c|c|c|c|c|}
\hline \multirow[t]{2}{*}{ Locality } & \multirow[t]{2}{*}{ (Municipality) } & \multirow[t]{2}{*}{ Coordinate } & \multirow[t]{2}{*}{$\begin{array}{l}\text { Altitude } \\
\quad(\mathbf{m})\end{array}$} & \multirow{2}{*}{$\begin{array}{l}\text { Field } \\
\text { work } \\
\text { period }\end{array}$} & \multirow[t]{2}{*}{ Vegetation type } & \multicolumn{2}{|c|}{$\begin{array}{c}\text { Sampling Effort } \\
\text { (trap.nights) }\end{array}$} \\
\hline & & & & & & $\begin{array}{c}\text { Sherman/ } \\
\text { Tomahawk }\end{array}$ & Pitfall \\
\hline $\begin{array}{l}\text { Foz do Córrego } \\
\text { do Brejão (4) }\end{array}$ & (Palmeiras) & $\begin{array}{l}12^{\circ} 25^{\prime} \mathrm{S} \\
41^{\circ} 25^{\prime} \mathrm{W}\end{array}$ & 532 a 842 & May, 2004 & $\begin{array}{l}\text { Semi-deciduous } \\
\text { Forest }\end{array}$ & 640 & 0 \\
\hline $\begin{array}{l}\text { Torre da Tele } \\
\text { Bahia (20) }\end{array}$ & (Lençóis) & $\begin{array}{l}12^{\circ} 32^{\prime} \mathrm{S} \\
41^{\circ} 24^{\prime} \mathrm{W}\end{array}$ & 520 a 643 & $\begin{array}{l}\text { January, } \\
2002\end{array}$ & $\begin{array}{l}\text { Cerrado sensu } \\
\text { stricto }\end{array}$ & 3,910 & 0 \\
\hline Remanso (23) & (Lençóis) & $\begin{array}{l}12^{\circ} 36^{\prime} \mathrm{S} \\
41^{\circ} 21^{\prime} \mathrm{W}\end{array}$ & 444 a 516 & $\begin{array}{l}\text { January, } \\
2002\end{array}$ & $\begin{array}{l}\text { Semi-deciduous } \\
\text { Forest }\end{array}$ & 3,810 & 2,496 \\
\hline $\begin{array}{l}\text { Estação de Tratamento } \\
\text { de Âgua de Mucugê (25) }\end{array}$ & (Mucugê) & $\begin{array}{l}12^{\circ} 59^{\prime} \mathrm{S} \\
41^{\circ} 23^{\prime} \mathrm{W}\end{array}$ & 983 a 1008 & $\begin{array}{l}\text { September, } \\
2004\end{array}$ & Gallery Forest & 210 & 0 \\
\hline Pousada Pé de Serra (26) & (Mucugê) & $\begin{array}{l}13^{\circ} 00^{\prime} \mathrm{S} \\
41^{\circ} 22^{\prime} \mathrm{W}\end{array}$ & 1000 a 1022 & $\begin{array}{l}\text { September, } \\
2004\end{array}$ & Rocky Savannas & 210 & 0 \\
\hline $\begin{array}{l}\text { Mata do Zé Leandro (27) } \\
\text { (Parque Estadual Sempre-Viva) }\end{array}$ & (Mucugê) & $\begin{array}{l}13^{\circ} 00^{\prime} \mathrm{S} \\
41^{\circ} 20^{\prime} \mathrm{W}\end{array}$ & 980 a 989 & $\begin{array}{l}\text { September, } \\
2004\end{array}$ & "Cerradão" & 360 & 0 \\
\hline Rio Cumbuca (28) & (Mucugê) & $\begin{array}{l}13^{\circ} 02^{\prime} \text { and } 03^{\prime} \mathrm{S} \\
41^{\circ} 20^{\prime} \text { and } 21^{\prime} \mathrm{W}\end{array}$ & 983 a 1043 & May, 2004 & Rocky Savannas & 720 & 0 \\
\hline $\begin{array}{l}\text { Margem do } \\
\text { Rio Saminas (29) }\end{array}$ & (Iatetê) & $\begin{array}{l}13^{\circ} 09^{\prime} \text { and } 11^{\prime} \mathrm{S} \\
41^{\circ} 10^{\prime} \text { and } 11^{\prime} \mathrm{W}\end{array}$ & 813 a 877 & May, 204 & $\begin{array}{l}\text { Semi-deciduous } \\
\text { Forest } \\
\text { Rocky Savannas }\end{array}$ & 10,49 & 175 \\
\hline
\end{tabular}

Table 2. Non-flying mammal list of Chapada Diamantina, including each species' conservation status (Machado et al., 2008; IUCN, 2008). M = museum record (MN and/or MVZ and/or MZUSP); $\mathrm{L}=$ literature (Oliveira \& Pêssoa, 2005); $\mathrm{C}=$ specimen collected during the present study; $\mathrm{O}=$ observation; $\mathrm{E}=$ interview*.

Tabela 2. Lista de mamíferos não voadores da Chapada Diamantina, incluindo o estado de conservação de cada espécie (Machado et al., 2008; IUCN, 2008). M = dado de museu (MN ou MVZ e/ou MZUSP); L = literatura (Oliveira \& Pêssoa, 2005); C = espécime coletado durante o presente estudo; O = observação; $\mathrm{E}=$ entrevista.

\begin{tabular}{|c|c|c|c|c|}
\hline & \multirow[t]{2}{*}{ Species } & \multirow[t]{2}{*}{ Record } & \multicolumn{2}{|c|}{ Conservation status } \\
\hline & & & IBAMA 2008 & IUCN \\
\hline Order Didelphimorphia & Didelphis albiventris Lund, 1840 & $\mathrm{C} / \mathrm{M} / \mathrm{L}$ & - & - \\
\hline Family Didelphidae & Gracilinanus agilis (Burmeister, 1854) & $\mathrm{M} / \mathrm{L}$ & - & Least Concern \\
\hline \multirow[t]{7}{*}{ Subfamily Didelphinae } & Gracilinanus microtarsus (Wagner, 1842) & $\mathrm{C} / \mathrm{L}$ & - & Least Concern \\
\hline & Marmosops incanus (Lund, 1840) & $\mathrm{C} / \mathrm{M} / \mathrm{L}$ & - & Least Concern \\
\hline & Marmosa murina (Linnaeus, 1758) & M & - & Least Concern \\
\hline & Micoureus demerarae (Thomas, 1905) & $\mathrm{C} / \mathrm{M} / \mathrm{L}$ & - & Least Concern \\
\hline & Monodelphis americana (Müller, 1776) & $\mathrm{L}$ & - & Least Concern \\
\hline & Monodelphis domestica (Wagner, 1842) & $\mathrm{C} / \mathrm{L}$ & - & Least Concern \\
\hline & Thylamys karimii (Petter, 1968) & $\mathrm{C}$ & Data-deficient & Vulnerable \\
\hline \multicolumn{5}{|l|}{ Order Cingulata } \\
\hline \multicolumn{5}{|l|}{ Family Casypodidae } \\
\hline Subfamily Dasypodinae & Dasypus novemcinctus Linnaeus, 1758 & $\mathrm{C} / \mathrm{L}$ & - & Least Concern \\
\hline Subfamily Euphractinae & Euphractus sexcinctus (Linnaeus, 1758) & $\mathrm{C}$ & - & - \\
\hline Subfamily Tolipeutinae & Cabassous tatouay (Desmarest, 1804) & $\mathrm{C}$ & Data Deficient & Least Concern \\
\hline \multicolumn{5}{|l|}{ Order Pilosa } \\
\hline Suborder Vermilingua & Myrmecophaga tridactyla Linnaeus, 1758 & $\mathrm{E}$ & Vulnerable & - \\
\hline Family Myrmecophagidae & Tamandua tetradactyla (Linnaeus, 1758) & $\mathrm{M} / \mathrm{E} / \mathrm{L}$ & - & Least Concern \\
\hline \multicolumn{5}{|l|}{ Order Primates } \\
\hline \multicolumn{5}{|l|}{ Infraorder Simiiformes } \\
\hline \multicolumn{5}{|l|}{ Parvorder Platyrrhini } \\
\hline Family Cebidae & Callithrix jacchus (Linnaeus, 1758) & $\mathrm{C}$ & - & Least Concern \\
\hline Subfamily Callitrichinae & Callithrix penicillata (É. Geoffroy, 1812) & $\mathrm{L}$ & - & Least Concern \\
\hline Subfamily Cebinae & Cebus xanthosternos Wied-Neuwied, 1826 & $\mathrm{E}$ & Critically endangered & Critically endangered \\
\hline \multicolumn{5}{|l|}{ Family Pitheciidae } \\
\hline Subfamily Callicebinae & Callicebus personatus (É. Geoffroy, 1812) & $\mathrm{E}$ & Vulnerable & Vulnerable \\
\hline \multicolumn{5}{|l|}{ Family Atelidae } \\
\hline Subfamily Alouattinae & Alouatta caraya (Humboldt, 1812) & $\mathrm{E}$ & Critically endangered & Least Concern \\
\hline \multicolumn{5}{|l|}{ Order Lagomorpha } \\
\hline Family Leporidae & Sylvilagus brasiliensis (Linnaeus, 1758) & $\mathrm{M} / \mathrm{O} / \mathrm{L}$ & - & Least Concern \\
\hline
\end{tabular}


Table 2. Continued...

\begin{tabular}{|c|c|c|c|c|}
\hline & \multirow[t]{2}{*}{ Species } & \multirow[t]{2}{*}{ Record } & \multicolumn{2}{|c|}{ Conservation status } \\
\hline & & & IBAMA 2008 & IUCN \\
\hline \multicolumn{5}{|l|}{ Order Carnivora } \\
\hline Suborder Feliformia & Leopardus sp. (Gray, 1842) & $\mathrm{E}$ & - & - \\
\hline Family Felindae & Puma concolor (Linnaeus, 1771) & $\mathrm{E}$ & Vulnerable & Least Concern \\
\hline Subfamily Felinae & Puma yagouarondi (Lacépède, 1809) & $\mathrm{O}$ & - & Least Concern \\
\hline Subfamily Pantherinae & Panthera onca (Linnaeus, 1758) & $\mathrm{E}$ & Vulnerable & Near Threatened \\
\hline \multirow{2}{*}{$\begin{array}{l}\text { Suborder Caniformia } \\
\text { Family Canidae }\end{array}$} & Cerdocyon thous (Linnaeus, 1766) & $\mathrm{C} / \mathrm{M} / \mathrm{L}$ & - & - \\
\hline & Lycalopex vetulus (Lund, 1842) & $\mathrm{O}$ & - & Least Concern \\
\hline \multirow{2}{*}{$\begin{array}{l}\text { Family Mustelidae } \\
\text { Subfamily Mustelinae }\end{array}$} & Eira barbara (Linnaeus, 1758) & $\mathrm{E} / \mathrm{L}$ & - & Least Concern \\
\hline & Galictis vittata (Schreber, 1776) & $\mathrm{M} / \mathrm{O} / \mathrm{L}$ & - & Least Concern \\
\hline \multirow[t]{2}{*}{ Family Procyonidae } & Nasua nasua (Linnaeus, 1766) & $\mathrm{E}$ & - & Least Concern \\
\hline & Procyon cancrivorous (G.[Baron] Cuvier, 1798) & $\mathrm{L}$ & - & - \\
\hline \multicolumn{5}{|l|}{ Order Artiodactyla } \\
\hline Family Tayassuidae & Pecari tajacu (Linnaeus, 1758) & $\mathrm{M} / \mathrm{L}$ & - & Least Concern \\
\hline Family Cervidae & Mazama sp. & $\mathrm{E} / \mathrm{L}$ & - & - \\
\hline \multicolumn{5}{|l|}{$\begin{array}{l}\text { Suborder Sciuromorpha } \\
\text { Family Sciuridae } \\
\text { Subfamily Sciurinae } \\
\text { Tribe Sciurini }\end{array}$} \\
\hline \multirow{16}{*}{$\begin{array}{l}\text { Order Rodentia } \\
\text { Suborder Myomorpha } \\
\text { Superfamily Muroidea } \\
\text { Family Cricetidae } \\
\text { Subfamily Sigmodontinae }\end{array}$} & Akodon cursor (Winge, 1887) & $\mathrm{C} / \mathrm{M} / \mathrm{L}$ & - & Least Concern \\
\hline & Calomys expulsus (Lund, 1840) & $\mathrm{C} / \mathrm{M} / \mathrm{L}$ & - & Least Concern \\
\hline & Cerradomys vivoi Percequillo et al. 2008 & $\mathrm{C} / \mathrm{M} / \mathrm{L}$ & - & - \\
\hline & Necromys lasiurus (Lund, 1840) & $\mathrm{C} / \mathrm{M} / \mathrm{L}$ & - & Least Concern \\
\hline & Nectomys squamipes (Brants, 1827) & $\mathrm{C} / \mathrm{L}$ & - & Least Concern \\
\hline & Nectomys rattus (Peters, 1860) & $\mathrm{L}$ & - & Least Concern \\
\hline & Oligoryzomys fornesi (Massoia, 1973) & $\mathrm{C}$ & - & Least Concern \\
\hline & Oligoryzomys nigripes (Olfers, 1818) & $\mathrm{C} / \mathrm{M} / \mathrm{L}$ & - & Least Concern \\
\hline & $\begin{array}{l}\text { Oligoryzomys rupestris Bonvicino \& } \\
\text { Weksler, } 2006\end{array}$ & $\mathrm{C} / \mathrm{L}$ & - & Data Deficient \\
\hline & $\begin{array}{l}\text { Oligoryzomys stramineus Bonvicino \& } \\
\text { Weksler, } 1998\end{array}$ & $\mathrm{~L}$ & - & Least Concern \\
\hline & Oxymycterus dasytrichus (Schinz, 1821) & $\mathrm{L}$ & - & Least Concern \\
\hline & Oxymycterus delator Thomas, 1903 & $\mathrm{~L}$ & - & Least Concern \\
\hline & Pseudoryzomys simplex (Winge, 1887) & $\mathrm{C} / \mathrm{M}$ & - & Least Concern \\
\hline & Rhipidomys cariri Tribe, 2006 & $\mathrm{~L}$ & - & Data Deficient \\
\hline & Rhipidomys sp. & $\mathrm{C} / \mathrm{M}$ & - & - \\
\hline & Wiedomys pyrrhorhinos (Wied-Neuwied, 1821) & $\mathrm{C} / \mathrm{M} / \mathrm{L}$ & - & Least Concern \\
\hline $\begin{array}{l}\text { Suborder Hystricomorpha } \\
\text { Family Caviidae } \\
\text { Subfamily Caviinae }\end{array}$ & Galea spixii (Wagler, 1831) & $\mathrm{M} / \mathrm{O}$ & - & Least Concern \\
\hline \multirow[t]{2}{*}{ Subfamily Hydrochoerinae } & $\begin{array}{l}\text { Hydrochoerus hydrochaeris (Linneaus, } \\
\text { 1766) }\end{array}$ & $\mathrm{E}$ & - & - \\
\hline & Kerodon rupestris (Wied, 1821) & $\mathrm{O} / \mathrm{L} / \mathrm{E}$ & - & Least Concern \\
\hline Family Dasyproctidae & Dasyprocta azarae Lichtenstein, 1823 & $\mathrm{E}$ & - & Data Deficient \\
\hline Family Cuniculidae & Cuniculus paca (Linnaeus, 1766) & $\mathrm{E}$ & - & - \\
\hline \multicolumn{5}{|l|}{ Family Echimyidae } \\
\hline Subfamily Echimyinae & Phyllomys blainvillii (Jordan, 1837) & M & Data Deficient & Data Deficient \\
\hline \multirow[t]{3}{*}{ Subfamily Eumysopinaae } & Thrichomys inermis (Pictet, 1941) & $\mathrm{C} / \mathrm{M} / \mathrm{L}$ & - & Data Deficient \\
\hline & Trinomys albispinus (I. Geoffroy, 1838) & $\mathrm{M} / \mathrm{L}$ & Data Deficient & - \\
\hline & Trinomys minor (Reis \& Pessoa, 1995) & $\mathrm{M} / \mathrm{L}$ & - & - \\
\hline
\end{tabular}

* Persons interviewed. Mr. Eugênio (ex-director of Chapada Diamantina National Park) and informers on the Management Plan meeting for the same National Park. 
Mammals of Chapada Diamantina

Table 3. Municipalities and localities in Chapada Diamantina with records of mammal species, and their coordinates. Localities marked with an* were sampled in the present study. Numbers in parentheses correspond to localities plotted in Figure 1. - corresponds that the coordinates were not available.

Tabela 3. Municípios e localidades da Chapada Diamantina com registro de espécies mamíferos e suas coordenadas geográficas. As localidades marcadas com * foram amostrados no presente estudo. Números em parênteses correspondem a localidades plotadas na Figura 1. - corresponde a coordenadas geográficas não disponíveis.

\begin{tabular}{|c|c|c|}
\hline Municipality & Locality & Coordinates \\
\hline Abaíra & Catolés (30) & $13^{\circ} 29^{\prime} \mathrm{S}$ and $41^{\circ} 84^{\prime} \mathrm{W}$ \\
\hline Andaraí & Fazenda Santa Rita (24) & $12^{\circ} 48^{\prime} \mathrm{S}$ and $41^{\circ} 15^{\prime} \mathrm{W}$ \\
\hline Aracatu & Rodovia de Vitória da Conquista para Rio de Contas (31) & $14^{\circ} 42^{\prime} \mathrm{S}$ and $41^{\circ} 46^{\prime} \mathrm{W}$ \\
\hline Itaetê & Rio Saminas* (29) & $13^{\circ} 10^{\prime} \mathrm{S}$ and $41^{\circ} 10^{\prime} \mathrm{W}$ \\
\hline \multirow[t]{4}{*}{ Lençóis } & Morro Torre TeleBahia* (20) & $12^{\circ} 32^{\prime} \mathrm{S}$ and $41^{\circ} 23^{\prime} \mathrm{W}$ \\
\hline & Remanso* (23) & $12^{\circ} 34^{\prime} \mathrm{S}$ and $41^{\circ} 21^{\prime} \mathrm{W}$ \\
\hline & Lençóis (22) & $12^{\circ} 56^{\prime} \mathrm{S}$ and $41^{\circ} 39^{\prime} \mathrm{W}$ \\
\hline & Santa Lagoa Seca (21) & - \\
\hline \multirow[t]{3}{*}{ Morro do Chapéu } & Km165 Rodovia do Feijão (1) & $11^{\circ} 55^{\prime} \mathrm{S}$ and $41^{\circ} 15^{\prime} \mathrm{W}$ \\
\hline & Morro do Chapéu (2) & - \\
\hline & Lages (3) & - \\
\hline \multirow[t]{4}{*}{ Mucugê } & Mata do Zé Leandro* (27) & $13^{\circ} 00^{\prime} \mathrm{S}$ and $41^{\circ} 20^{\prime} \mathrm{W}$ \\
\hline & Estação de Tratamento de Água* (25) & $12^{\circ} 59^{\prime} \mathrm{S}$ and $41^{\circ} 23^{\prime} \mathrm{W}$ \\
\hline & Pousada Pé de Serra* (26) & $13^{\circ} 00^{\prime} \mathrm{S}$ and $41^{\circ} 22^{\prime} \mathrm{W}$ \\
\hline & Rio Cumbuca* (28) & $13^{\circ} 02^{\prime} \mathrm{S}$ and $41^{\circ} 21^{\prime} \mathrm{W}$ \\
\hline \multirow[t]{8}{*}{ Palmeiras } & Campos de São João (13) & $12^{\circ} 52^{\prime} \mathrm{S}$ and $41^{\circ} 55^{\prime} \mathrm{W}$ \\
\hline & Foz do Córrego do Brejão* (4) & $12^{\circ} 25^{\prime} \mathrm{S}$ and $41^{\circ} 25^{\prime} \mathrm{W}$ \\
\hline & Santo Ananaz (14) & $12^{\circ} 52^{\prime} \mathrm{S}$ and $41^{\circ} 55^{\prime} \mathrm{W}$ \\
\hline & Santo Boqueirão (15) & - \\
\hline & Fazenda Conceição (16) & - \\
\hline & Fazenda Rio Preto (17) & - \\
\hline & Fazenda Fervedor (18) & - \\
\hline & Fazenda Pau Ferro (19) & - \\
\hline \multirow[t]{8}{*}{ Seabra } & Fazenda Furados (5) & $12^{\circ} 41^{\prime} \mathrm{S}$ and $41^{\circ} 77^{\prime} \mathrm{W}$ \\
\hline & Santa Baixa Redonda (6) & - \\
\hline & Santa Torrinha (7) & - \\
\hline & São Lapão 2 (8) & - \\
\hline & Santa Cajazeira (9) & - \\
\hline & Santa Gameleira (10) & - \\
\hline & Fazenda Lapinha (11) & - \\
\hline & Fazenda Suera (12) & - \\
\hline
\end{tabular}

(four) and observations (one). Out of the 316 specimens recorded during field work (Table 2), $237(75 \%)$ are rodents, $69(22 \%)$ are marsupials, five $(1.5 \%)$ are armadillos, three are carnivores $(1.24 \%)$ and one is a primate $(0.32 \%)$. Our database, including museum records, totalized 590 specimens of mammals (see Appendix).

Seven species are cited in the Brazilian official list of endangered species (Machado et al. 2008 - IBAMA; IUCN 2008). The fat-tailed mouse opossum (Thylamys karimii) is considered Vulnerable by IUCN and Data-deficient by IBAMA. The giant anteater (Myrmecophaga tridactyla) is considered Vulnerable by IBAMA, but do not appear in the IUCN list. Three monkeys are presented in both list: Alouatta caraya (Critically endangered - IBAMA and Least Concern - IUCN), Cebus xanthosternus (Critically endangered in both lists) and Callicebus personatus (Vulnerable in both lists). Two felines are also present in both lists: Panthera onca (Vulnerable - IBAMA and Near Threatened - IUCN) and Puma concolor (Vulnerable - IBAMA and Least Concern - IUCN). Another six species (one armadillo, Cabassous tatouay; and six rodents, Oligoryzomys rupestris, Rhipidomys cariri, Dazyprocta azarae, Phyllomys blainvilli, Thrichomys inermis and Trinomys albispinus) are classified as data-deficient species in both or one of the lists (Machado et al. 2008 - IBAMA; IUCN 2008).

\section{Habitat comparisons}

Despite differences in capture effort (Table 1), species richness of small non-flying mammals was similar among the most sampled vegetation formations (Figure 2): 10 species were obtained in semi-deciduous forests, nine in rocky savanna and eight in cerrado sensu stricto. Comparison of the data obtained in open vegetation habitats (rocky savanna and cerrado sensu stricto) shows that although rocky savanna had one third of capture effort, when compared to cerrado sensu stricto $(1,616$ and 3,910 trap.nights, respectively), it has a higher species richness (nine species in rocky savanna and eight in cerrado sensu stricto).

Species composition differed among vegetation formations (Figures 3, 4 and 5). Oligoryzomys nigripes, O. fornesi and Rhipidomys $\mathrm{sp}$. were collected only in the semi-deciduous forest, whereas Calomys expulsus, Pseudoryzomys simplex and Wiedomys pyrrhorhinos were recorded only in open vegetation (rocky savanna). However, species that were not habitat-dependent, such as Akodon cursor, trapped in semi-deciduous forest and in cerrado sensu stricto, and Cerradomys vivoi, sampled in all habitats surveyed (Table 4). Eight species were collected only in open vegetation habitats, five species only in forested habitats, and five in both (Table 4). 


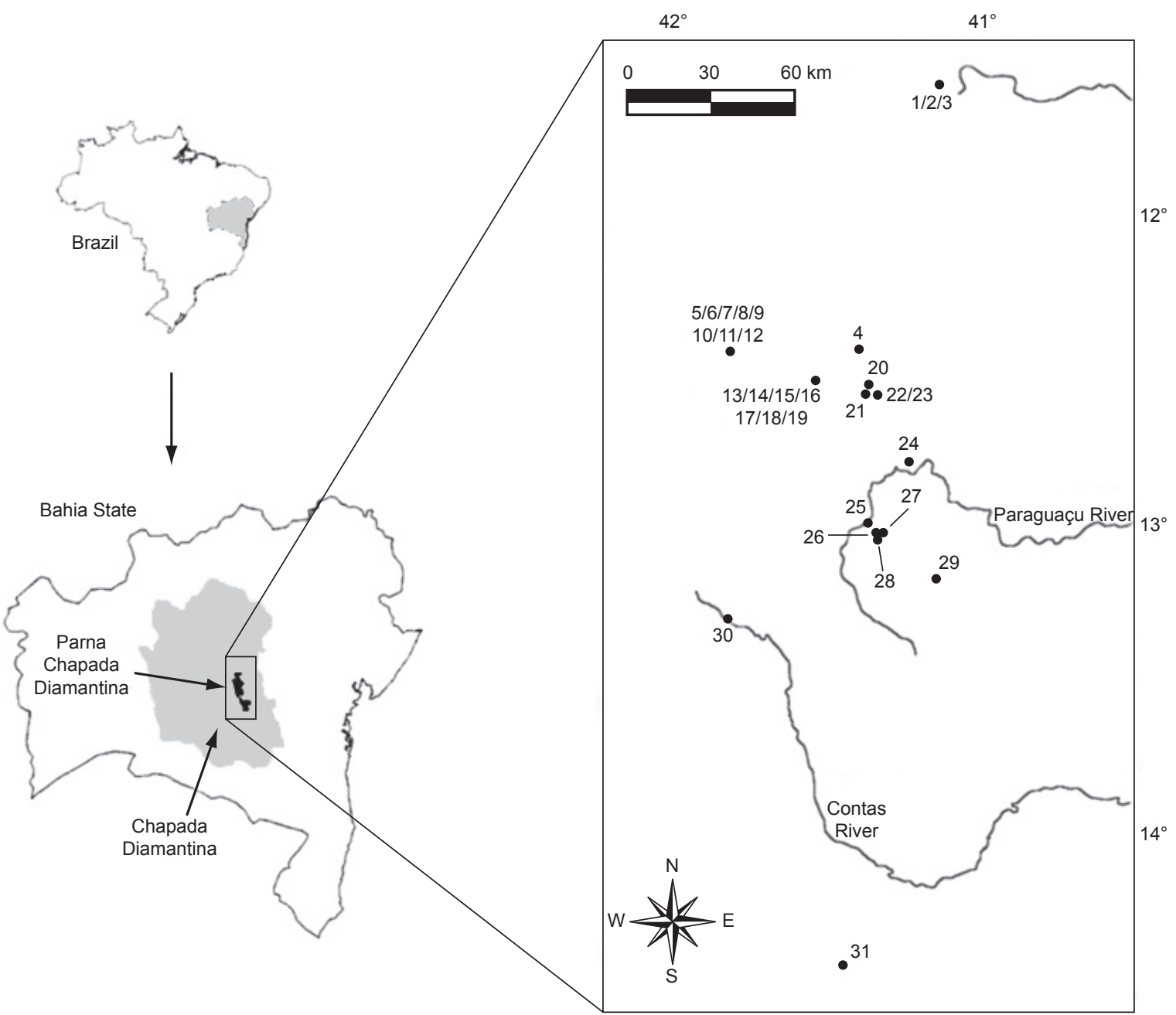

Figure 1. Map of localities with records of mammals in Chapada Diamantina, Bahia, Brazil. The numbers correspond to each locality described in Table 3 Figura 1. Mapa das localidades com registro de mamíferos na Chapada Diamantina, Bahia, Brasil. Os números correspondem a cada localidade descrita na tabela 3.

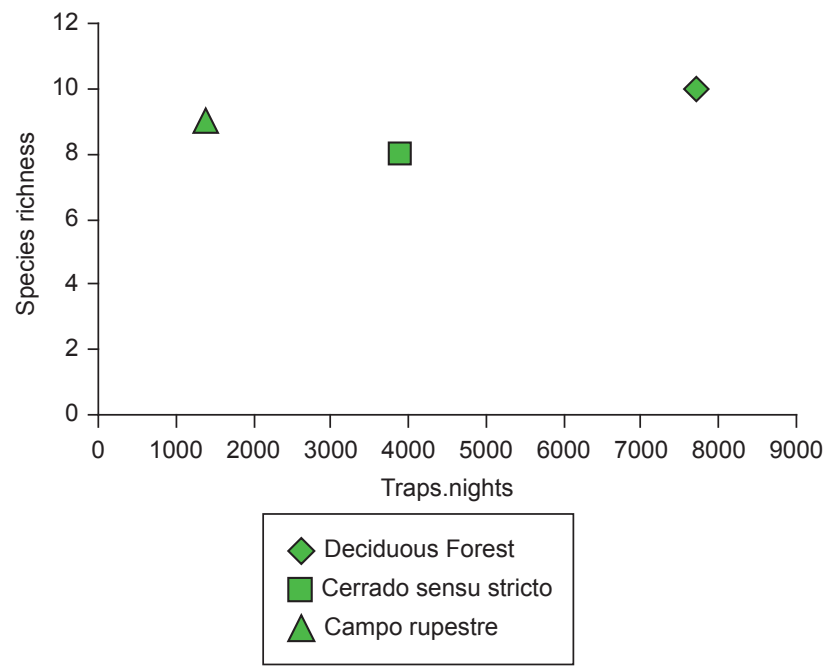

Figure 2. Relationship between species richness and the number of trap.nights for the vegetation types more sampled.

Figura 2. Relação entre a riqueza de espécies e o número de armadilhas. noites em cada tipo de vegetação mais amostrados.

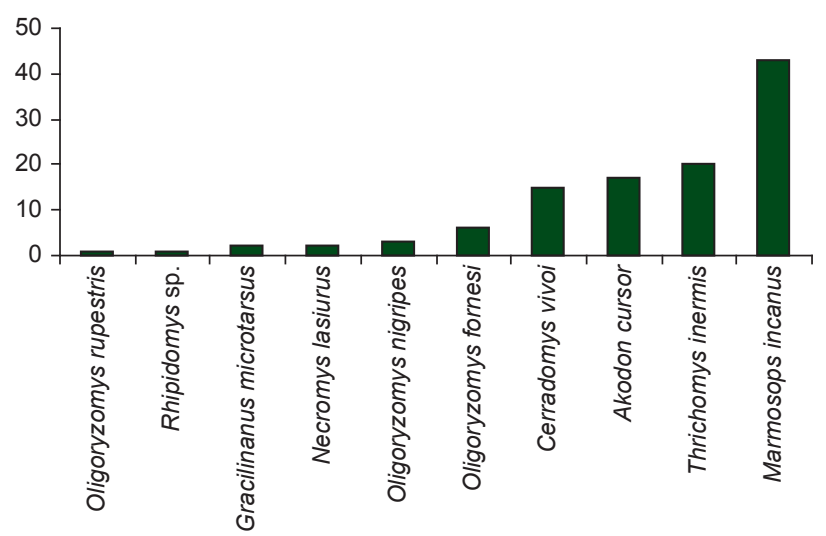

Figure 3. Species and number of individuals collected in semi-deciduous forest.

Figura 3. Espécies e números de indivíduos coletados na Floresta Semidecidual. 


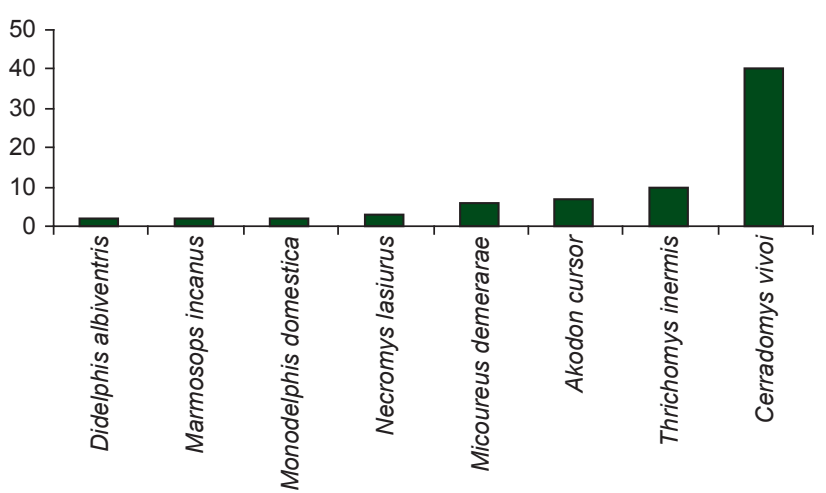

Figure 4. Species and number of individuals collected in cerrado sensu stricto.

Figura 4. Espécies e números de indivíduos coletados no cerrado sensu stricto.

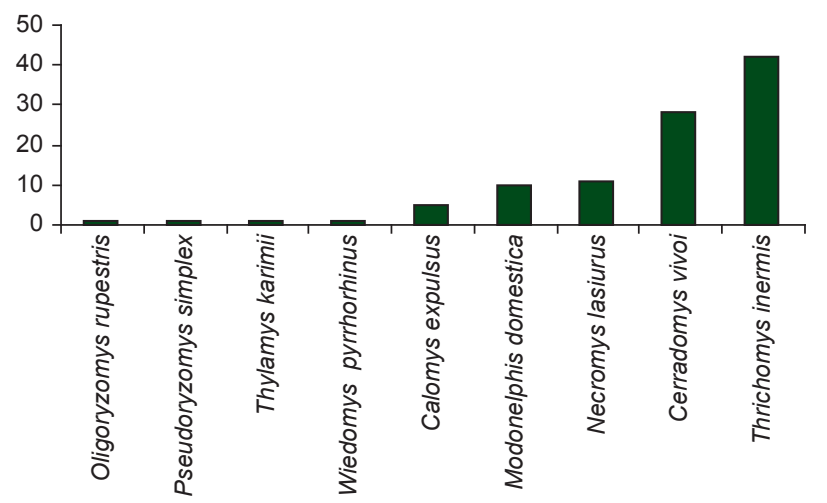

Figure 5. Species and number of individuals collected in "campo rupestre" Figura 5. Espécies e números de indivíduos coletados no campo rupestre.

Species frequencies were not equivalent in each vegetation formation. Marmosops incanus was the most common species in semideciduous forest with 43 individuals captured, Cerradomys vivoi was the most common in cerrado sensu stricto with 40 individuals, and Thrichomys inermis was the most common species (42 individuals) captured in the rocky savanna (Figures 3 to 5). Besides, Cerradomys vivoi and Thrichomys inermis were among the most four common species. Cerradomys vivoi correspond to $86 \%$ of the specimens collected in "cerradão", $64 \%$ in gallery forest, $55 \%$ in cerrado sensu stricto, $28 \%$ in rocky savanna, and $14 \%$ in semi-deciduous forest. Thrichomys inermis present $42 \%$ of individuals captured in rocky savanna, $18 \%$ in semi-deciduous forest and gallery forest, and $14 \%$ in cerrado sensu stricto. Among the arboreal species, Gracilinanus microtarsus and Rhipidomys sp. were collected in semi-deciduous forest, Micoureus demerarae in cerrado sensu stricto, and Marmosops incanus in both semi-deciduous forest and cerrado sensu stricto (Table 4, Figures 3, 4 and 5). In those three localities where traps were settled in semi-deciduous forest, $M$. incanus was the most abundant species (39\%), but it was the scarcest in those localities with open vegetation, with less than five specimens $(2.7 \%)$ in cerrado sensu stricto (Figure 4), and absent in rocky savanna, gallery forest and "cerradão" (Figure 5).
Table 4. List of species collected in each habitat sampled. Vegetations types: DF (Semi-deciduous forest), RS (rocky savanna), CE (cerrado sensu stricto) and GF (gallery forest)

Tabela 4. Lista de espécies coletadas em cada habitat amostrado. Tipos vegetacionais: DF (Floresta Semi-decidual), RS (campo rupestre), CE (cerrado sensu stricto), e GF (Floresta de Galeria).

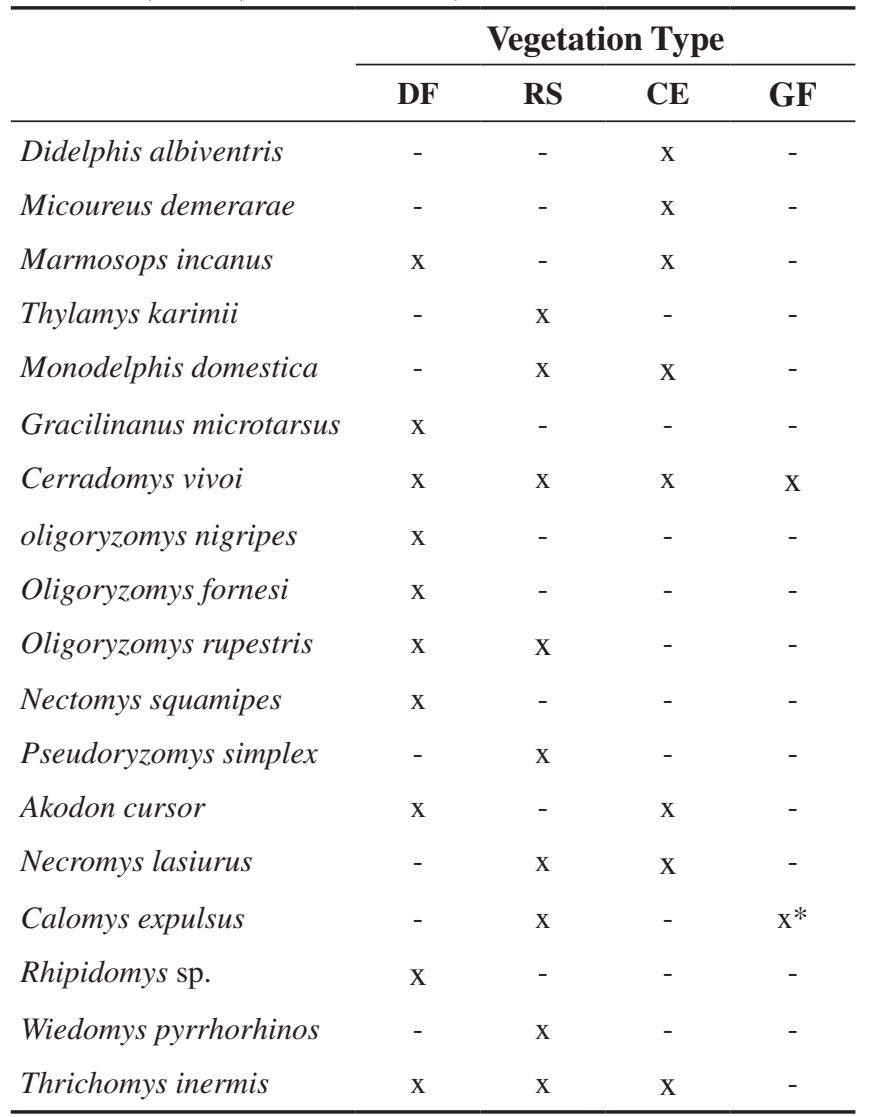

* Collected in a pasture land in the middle of the gallery forest.

\section{Discussion}

Here we are presenting the results of a mammal sampling effort in the Chapada Diamantina, as described in Table 1. In Chapada Diamantina 58 non-flying mammal species were recorded, including 34 species of small non-flying mammals, nine marsupials from the Family Didelphidae, and 25 species of rodents (excluding Hydrochoerus hydrochaeris), one of the Family Sciuridae, 16 of the Family Cricetidae, two of the Family Caviidae, one of the Family Dasyproctidae, one of the Family Cuniculidae, and four of the Family Echimyidae.

Since the complete Chapada Diamantina was not surveyed, more field work is necessary to provide more detailed information about mammals' occurrence. Long-term studies can generate longer species list, as observed by Olifiers et al. (2007) with an effort of 59,290 trap. nights. According to those authors, at Serra dos Órgãos National Park, in Rio de Janeiro state, where a five-year long survey (1996 to 2000) was carried out, 27 small mammal species were registered, including rodents and marsupials, but Juliomys rimofrons and J. ossitenius were only trapped at the end of the study (Olifiers et al. 2007). The trapping effort made by the authors during five expeditions to Chapada Diamantina (13,568 trap.nights), with sporadic collecting effort, does 
not provide a mammal list for the region that can be considered nearly completion. As an example, among the non-flying small mammals, the addition of Monodelphis americana, Nectomys rattus, Oxymycterus dasytrichus, $O$. delator, Trinomys albistinus and T. minor follows Souza (2005) and Oliveira \& Pêssoa (2005), since we do not sampled this taxa. On the other hand, Souza (2005) and Oliveira \& Pêssoa (2005) did not record Thylamys karimii, Wiedomys pyrrhorhinos and Pseudoryzomys simplex, which were sampled during our field sampling and thus included in the present list.

The number of mammals species herein recorded in 13,568 trap. nights, together with the information obtained from museums and the literature, is comparable, in terms of number of species, to the list of Itatiaia National Park, with 69 species (Geise et al. 2004), which shows that in spite of the difference of vegetation types, these two regions exhibit a similar species richness. Itatiaia National Park has only Atlantic Forest areas, a very humid climate, with tropical wet forest and grassland altitude fields ("campos de altitude") habitats whereas Chapada Diamantina National Park harbors areas of Atlantic Forest, Caatinga and Cerrado.

If a comparison of species richness and vegetation types can be made, as already suggested by Oliveira \& Pessôa (2005) that would be with the Chapada dos Veadeiros and Chapada Diamantina. Comparing the species composition between these two areas, we observed that nine species (five rodents and four marsupials) were found in both Chapadas (Bonvicino et al. 2005 and the present study): the similarity of species composition was about $15 \%$, and the species that occurs in both Chapadas are Didelphis albiventris, Gracilinanus agilis, Monodelphis domestica, Micoureus demerarae, Calomys expulsus, Necromys lasiurus, Oligoryzomys rupestris, Oxymycterus delator, and Pseudoryzomys simplex. All these species are characteristic of open vegetations from Cerrado (see Carmignotto, 2004), corroborating the similarity between Chapada Diamantina and Chapada dos Veadeiros.

Some species reported by us here have had their known geographic distribution extended. Gracilinanus microtarsus known distribution, according to Patton \& Costa (2003), Costa et al. (2003), and the IUCN Global Mammal Assessment (IUCN 2008), ranges from Paraná state to northern Rio de Janeiro and southern Minas Gerais states, with an isolated record of G. microtarsus from Una, southern Bahia (Pardini, 2004). The record of Chapada Diamantina presented here is the second for the state, extending the species distribution to one of the few and most important forest remnants in the northeast Brazil (Câmara, 2003). Oligoryzomys rupestris was, until now, observed in two localities: Alto Paraíso (Minas Gerais) and Pico das Almas (Bahia) (Weksler \& Bonvicino 2005). The collected specimens at Chapada Diamantina increased the species northernmost limit by $92 \mathrm{~km}$ (from $13^{\circ} 33^{\prime} \mathrm{S}$ and $41^{\circ} 56^{\prime} \mathrm{W}$ to $13^{\circ} 10^{\prime} \mathrm{S}$ and $41^{\circ} 10^{\prime} \mathrm{W}$ ). The current northernmost occurrence of Cabassous tatouay was in Minas Gerais state, at Igarapé municipality (2004' 13.8" S-44 18' 6.12"'W; E.M.V.C. Câmara, pers. comm), and the present record extends considerably the distribution of this species northwards, being also the first record to northeastern Brazil (Gardner, 2007). All these range expansions reflect the lack of available data on these species distribution ranges in the Neotropics.

We observed some representatives of the Atlantic Forest mammalian fauna, a similar pattern observed by Parrini et al. (1999), which reported species from different biomes occurring in sympatry in the Chapada Diamantina, pointing out a mosaic between faunal composition in open biomes (Cerrado-Caatinga) and forests (Atlantic Forest). Another point concerning the here reported mammal diversity is that the Caatinga area in Chapada Diamantina is considered as one of the priority areas for conservation because of the presence of contact areas with others biomes (Cerrado and Atlantic Forest), their isolation and a presumably high species diversity (Oliveira et al. 2003).
We believe that the occurrence of syntopic species in the Chapada Diamantina, from both open and forest habitats could indicate:

a) inadequate definition of their habitat specificities;

b) insufficient studies to properly define the patterns of geographical distribution;

c) the tendency to adapt to different habitats;

d) the lack of habitat specificity; and

e) the mosaic structure of vegetation of the region.

In the present study we recorded two species that are common to open areas (Cerrado and Caatinga), but that in Chapada Diamantina were found in forests (semi-deciduous Forest). Thrichomys inermis, which is usually found in dry environments like Caatinga and Cerrado (Basile 2003), was also captured by us in semi-deciduous forest (locality 4), as well as Oligoryzomys rupestris (Weksler \& Bonvicino 2005). In both cases the semi-deciduous forest area was located beside the rocky savanna.

The here now presented list of mammal species of Chapada Diamantina exhibits species of Atlantic Forest, Cerrado and Caatinga (Fonseca et al. 1996; Costa et al. 2000). Furthermore, some species are present in other environments than previously recorded. All characteristics herein mentioned turn Chapada Diamantina into a region of biogeographic importance, that present vegetations of three biomes and a mammal fauna that represent a transition region.

\section{Acknowledgements}

Authors are grateful to C. C. Aires, H. S. da Silva and P. S. Pinheiro for help during field activities. We are grateful to J. A. Oliveira (Museu Nacional do Rio de Janeiro) and M. de Vivo (Museu de Zoologia da USP) for the access granted to the museum collections. This work was supported by CNPq, CAPES, UERJ/Prociência, and Biota Fapesp.

\section{References}

BASILE, P. 2003. Taxonomia de Thrichomys Trouessart, 1880 (Rodentia, Echimyidae). Dissertação de Mestrado, Universidade de São Paulo, Ribeirão Preto.

BONVICINO, C.R. \& MOREIRA, M.A.M. 2001. Molecular phylogeny of the genus Oryzomys (Rodentia: Sigmodontinae) based on cytochrome $b$ DNA sequences. Mol. Phylog. Evol. 18(2):282-292.

BONVICINO, C.R. \& WEKSLER, M. 1998. A new species of Oligoryzomys (Rodentia, Sigmodontinae) from northeastern and central Brazil. Z Säugetierkd. 63:90-103.

BONVICINO, C.R., OTAZU, I.B. \& BORODIN, P.M. 1999. Chromosome variation in Oryzomys subflavus species group (Sigmodontinae, Rodentia) and its taxonomic implication. Cytol. 64:327-332.

BONVICINO, C.R., D’ANDREA, P.S. \& BORODIN, P.M. 2001. Pericentric inversion in natural populations of Oligoryzomys nigripes (Rodentia: Sigmodontinae). Geno. 44:1-6.

BONVICINO, C.R., OTAZU, I.B. \& D'ANDREA, P.S. 2002. Karyologic evidence of diversification of the genus Thrichomys (Rodentia, Echimyidae). Cytogenet. G. Res. 97:200-204.

BONVICINO, C.R., LIMA, J.F.S. \& ALMEIDA, F.C. 2003. A new species of Calomys Waterhouse (Rodentia, Sigmodontinae) from the Cerrado of Central Brazil. Braz. J. Biol. 20(2):301-307.

BONVICINO, C.R., LEMOS, B. \& WEKSLER, M. 2005. Small mammals of Chapada dos Veadeiros National Park (Cerrado of central Brazil): ecology, karyologic, and taxonomic considerations. Braz. J. Biol. 65(3):1-12.

BONVICINO, C.R., OLIVEIRA, J.A. \& D’ÁNDREA, P.S. 2008. Guia dos roedores do Brasil com chaves para gêneros baseadas em caracteres externos. Centro Pan-Americano de Febre Aftosa, Rio de Janeiro.

BRAZÃO, J.E.M. \& ARAÚJO, A.P. 1981. Vegetação. In Salvador: geologia, geomorfologia, pedologia, vegetação e uso potencial da terra. Projeto 
RadamBrasil. Ministério das Minas e Energia, Rio de Janeiro, p. 405-464. (folha SD 24). BUSH, M.B. 1994. Amazonian speciation: a necessarily complex model. J. Biogeogr. 21:5-17.

CÂMARA, I.G. 2003. Brief History of Conservation in the Atlantic Forest. In The Atlantic Forest of South America: biodiversity status, threats, and outlook (C. Galindo-Leal \& I.G. Câmara, eds.). Island Press, Washington, p. 31-42.

CARMIGNOTTO, A.P. 2004. Pequenos mamíferos terrestres do bioma Cerrado: padrões faunísticos locais e regionais. Tese de Doutorado, Universidade de São Paulo, São Paulo, 404 p.

CARNAVAL, A.C., HICKERSON, M.J., HADDAD, C.F.B., RODRIGUES, M.T. \& MORITZ, C. 2009. Stability predicts genetic diversity in the Brazilian Atlantic Forest Hotspot. Sci. 323(5915):785-789.

CARTELLE, C. 1999. Pleistocene mammals of the Cerrado and Caatinga of Brazil. In Mammals of the Neotropics: the Central Neotropics (J.F. Eisenberg \& K.H. Redford, eds.). University of Chicago Press, Chicago, p. 27-46. (v. 3).

CARTELLE, C. \& ABUHID, V.S. 1994. Chiroptera do Pleistoceno FinalHoloceno da Bahia. Ac. Geol. Leop. 39:429-440.

Conservation International do Brasil. 2000. Avaliação e ações prioritárias para a conservação da biodiversidade da Mata Atlântica e Campos Sulinos. MMA; SBF, Brasília.

CORRÊA, M.M.O., LOPES, M.O.G., CÂMARA, E.V.C., OLIVEIRA, L.C. \& PESSOA, L.M. 2005. The karyotypes of Trinomys moojeni (Pessoa, Oliveira \& Reis, 1992) and Trinomys setosus elegans (Lund, 1814) (Rodentia, Echimyidae) from Minas Gerais, eastern Brazil. Arq. Mus. Nac. 63(1):169-174.

COSTA, L.P. 2003. The historical bridge between the Amazon and the Atlantic forests of Brazil: a study of molecular phylogeography with small mammals. J. Biogeogr. 30:71-86.

COSTA, L.P., LEITE, Y.L.R., FONSECA, G.A.B. \&. FONSECA, M.T. 2000. Biogeography of South American forest mammals: endemism and diversity in the Atlantic Forest. Biotrop. 32(4b):872-881.

COSTA, L.P., LEITE, Y.L.R. \& PATTON, J.L. 2003. Phylogeography and systematic notes on two species of gracile mouse opossums, genus Gracilinanus (Marsupialia: Didelphidae) from Brazil. P. Biol. Soc. Wash. 116(2):275-292.

CZAPLEWSKI, N. \& CARTELLE, C. 1998. Pleistocene bats from cave deposits in Bahia, Br. J. Mammal. 79(3):784-803.

EISENBERG, J.F. 1999. The contemporary mammalian fauna of South America. In Mammals of the Neotropics: the Central Neotropics (J.F. Eisenberg \& K.H. Redford, eds.). University of Chicago Press, Chicago, p. 582-591. (v. 3).

EISENBERG, J.F. \& REDFORD, K.H. 1999. Mammals of the Neotropics: the Central Neotropics. University of Chicago Press, Chicago, 609 p. (v. 3).

EMMONS, L.H. \& FEER, F. 1997. Neotropical Rainforest Mammals: a field guide. 2 ed. University of Chicago Press, Chicago, 307 p.

FONSECA, G.A.B., HERMAN, G., LEITE, Y.L., MITTERMEIER, R., RYLANDS, A.B. \& PATTON, J.L. 1996. Lista anotada dos mamíferos do Brasil. Occ.Pap. Conser. Biol. 4:1-38.

GARDNER, A.L. 2007. Mammals of South America. University of Chicago Press, Chicago, 669 p. (v. 1, Marsupials, xenarthrans, shrews, and bats).

GEISE, L., PEREIRA, L.G., BOSSI, D.E.P. \& BERGALLO, H.G. 2004 Pattern of elevation distribution and richness of nonvolant mammals in Itatiaia National Park and its surrounding, in southeastern Brazil. Braz. J. Biol. 64(3):1-15.

GONÇALVES, P.R. \& OLIVEIRA, J.A. 2004. Morphological and genetic variation between two sympatric forms of Oxymycterus (Rodentia: Sigmodontinae): an evaluation of hypotheses of differentiation within the genus. J. Mammal. 85(1):148-161.

GONÇALVES, P.R., ALMEIDA, F.C. \& BONVICINO, C.R. 2005. A new species of Wiedomys (Rodentia: Sigmodontinae) from Brazilian Cerrado. Mammal. Biol. 70(1):46-60.
GREGORIN, R. \& MENDES, L.F. 1999. Sobre quirópteros (Emballonuridae, Phyllostomidae, Natalidae) de duas cavernas da Chapada Diamantina, Bahia, Brasil. Ihering., S. Zool. 86:121-124.

GRELLE, C.E.V. 2000. Areografia dos primatas endêmicos da Mata Atlântica. Tese de Doutorado, Universidade Federal do Rio de Janeiro, Rio de Janeiro.

GRELLE, C.E.V., ALVES, M.A.S., BERGALLO, H.G., GEISE, L., ROCHA, C.F.D., Van SLUYS, M. \& CARAMASCHI, U. 2005. Prediction of threatened tetrapods based on the species-area relationship in Atlantic Forest, Brazil. J. Zool. 265(4):359-364.

HERINGER, H. \& MONTENEGRO, M.M. 2000. Avaliação e ações prioritárias para a conservação da biodiversidade da Mata Atlântica e Campos Sulinos. Ministério do Meio Ambiente, Brasília, 40 p.

International Union for Conservation of Nature and Natural Resources - IUCN. 2008. Red List of threatened species. IUCN, Cambridge. Disponível em: http://www.iucnredlist.org/ (último acesso em 24/06/2009).

JUNCÁ, F.A., FUNCH, L. \& ROCHA, W. 2005. Biodiversidade e conservação da Chapada Diamantina. Ministério do Meio Ambiente, Brasília, $411 \mathrm{p}$.

LANGGUTH, A. \& BONVICINO, C.R. 2002. The Oryzomys subflavus species group, with description of two new species (Rodentia, Muridae, Sigmodontinae). Arq. Mus. Nac. 60(4):285-294.

LARA, M.C. \& PATTON, J.L. 2000. Evolutionary diversification of spiny rats (genus Trinomys, Rodentia: Echimyidae) in the Atlantic Forest of Brazil. Zool. J. Linn. Soc.130:661-686.

MACHADO, A.B.M., DRUMMOND, G.M. \& PAGLIA, A.P. 2008. Livro vermelho da fauna brasileira ameaçada de extinção. Ministério do Meio Ambiente, Belo Horizonte, 907 p. (Série Biodiversidade, v. 2, n. 19).

MORITZ, C., PATTON, J.L., SCHNEIDER, C.J. \& SMITH, T.B. 2000. Diversification of rainforest faunas: an integrated molecular approach. Ann. Rev. Ecol. Syst. 31:533-563.

MUSTRANGI, M.A. \& PATTON, J.L. 1997. Phylogeography and systematics of the slender mouse opossum Marmosops (Marsupialia, Didelphidae) University of California Press, Berkeley, 86 p. (Publications in Zoology, v. 130).

OLIFIERS, N., CUNHA, A.A., GRELLE, C.E., BONVICINO, C.R., GEISE, L., PEREIRA, L.G., VIEIRA, M.V., D'ANDREA, P.S. \& CERQUEIRA, R. 2007. Lista de espécies de pequenos mamíferos não-voadores do Parque Nacional da Serra dos Órgãos. In Ciência e Conservação na Serra dos Orgãos (C. Cronemberger \& E.B. Viveiros de Castro, orgs.). Instituto Chico Mendes de Conservação da Biodiversidade, Brasilia, p. 183-192.

OLIVEIRA, J.A. \& PÊSSOA, L.M. 2005. Mamíferos. In Biodiversidade e Conservação da Chapada Diamantina (F.A. Juncá, L. Funch \& W. Rocha, eds.). Ministério do Meio Ambiente, Brasília.

OLIVEIRA, J.A., GONÇALVES, P.R. \& BONVICINO, C.R. 2003. Mamíferos da Caatinga. In Ecologia e conservação da caatinga (I.R. Leal, M. Tabarelli \& J.M.C.D. Silva, eds.). Universidade Federal de Pernambuco, Recife.

PARDINÃS, U.F.J., D'ÉLIA, G. \& ORTIZ, P.E. 2002. Sigmodontinos fósiles (Rodentia, Muroidae, Sigmodontinae) de América del Sur: estado actual de su conocimiento y prospectiva. Mastoz. Neotrop. 9(2):209-252.

PARDINI, R. 2004. Effects of forest fragmentation on small mammals in an Atlantic Forest land- scape. Biod. and Conserv. 13:2567-2586.

PARRINI, R., RAPOSO, M.A., PACHECO, J.F., CARVALHÃES, A.M.P., MELO Jr., T.A., FONSECA, S.M. \& MINNS, J.C. 1999. Birds of the Chapada Diamantina, Bahia, Brazil. Cotinga. 11:86-95.

PATTON, J.L. \& COSTA, L.P. 2003. Molecular phylogeography and species limits in rainforest didelphid marsupials of South America. In Predators with pouches: the biology of carnivorous marsupials (M. Jones \& C.R. Dickman, eds.). CSIRO Publishing, Australia, p. 63-81.

PATTON, J.L., SILVA, M.N.F. \& MALCON, J.R. 2000. Mammals of the Rio Juruá and the evolutionary and ecological diversification of Amazonia. B. Am. Mus. Nat. Hist. 244:1-306.

PATTON, J.L., SILVA, M.N.F., LARA, M.C. \& MUSTRANGI, M.A. 1997. Diversity, differentiation, and the historical biogeography of nonvolant 
small mammals of the neotropical forests. In Tropical forest remnants: ecology, management, and conservation of fragmented communities (W.F. Laurence \& R.O. Bierrgaard JR., eds.). University of Chicago Press, Illinois, p. 455-465.

PERCEQUILLO, A.R. 1998. Sistemática de Oryzomys (Baird, 1858) do leste do Brasil (Muroidea, Sigmodontinae). Tese de Doutorado, Universidade de São Paulo, São Paulo, 552 p.

PERCEQUILlO, A.R., HINGST-ZAHER, E. \& BONVICINO, C.R. 2008. Systematic Review of Genus Cerradomys Weksler, Percequillo and Voss, 2006 (Rodentia: Cricetidae: Sigmodontinae: Oryzomyini), with Description of Two New Species from Eastern Brazil. Am. Mus. Novit. 3622:46.

PEREIRA, L.G. \& GEISE, L. 2007. Karyotype composition of some rodents and marsupials from Chapada Diamantina (Bahia - Brazil). Braz. J. Bio. 67(3):509-518.

PESSOA, L.M., CORRÊA, M.M.O., BITENCOURT, E. \& REIS, S.F. 2005. Chromosomal characterization of taxa of the genus Trinomys Thomas, 1921 (Rodentia, Echimyidae) in the states of Rio de Janeiro and São Paulo. Arq. Mus. Nac. 63(1):161-168.

PRANCE, G.T. 1992. Biogeography of neotropical plants. In Biogeography and quaternary history in Tropical America (T.C. Whitmore \& G.T. Prance, eds.). Columbia University Press, New York, p. 46-65.

REIG, O.A. 1986. Diversity patterns and differentiation of high Andean rodents. In High altitude tropical biogeography. (F. Vuilleumier \& M. Monasterio, eds.). Oxford University Press, Oxford, p. 404-439.

REIS, N.R., PERACCHI, A.L., PEDRO, W.A. \& LIMA, I.P. 2006. Mamíferos do Brasil. Universidade Estadual de Londrina, Londrina, 437 p.

RIZZINI, C.T. 1997. Tratado de Fitogeografia do Brasil: aspectos ecológicos, sociológicos e florísticos. 2 ed. Âmbito Cultura Edições Ltda., Rio de Janeiro, $747 \mathrm{p}$.

RODRIGUES-FILHO, S., BEHLING, H., IRION, G. \& MULLER, G. 2002. Evidence for lake formation as a response to an inferred Holocene climatic transition in Brazil. Quat. Res. 57(1):131-137.

SOUZA, A.L.G. 2005. Diversidade de espécies, variação cariotípica e distribuição dos roedores da Chapada Diamantina, Bahia. Dissertação de Mestrado, Universidade Federal do Rio de Janeiro, Rio de Janeiro.
TRIBE, C.J. 1996. The Neotropical rodent genus Rhipidomys (Cricetidae: Sigmodontinae): a taxonomic revision. Tese de Doutorado, University College London, London, 316 p.

TRIBE, C.J. 2005. A new species of Rhipidomys (Rodentia, Muroidea) from North-Eastern Brazil. Arq. Mus. Nac. 63(1):131-146.

VELOSO, H.P., FILHO, A.L.R.R. \& LIMA, J.C.A. 1991. Classificação da vegetação brasileira, adaptada a um sistema universal. Fundação IBGE, Rio de Janeiro, $123 \mathrm{p}$.

VIVO, M. 1997. Mammalian evidence of historical ecological change in the Caatinga semiarid vegetation of northeastern Brazil. J. Comp. Biol. 2:65-73.

VIVO, M. \& CARMIGNOTTO, A.P. 2004. Holocene vegetation change and the mammal faunas of South America and Africa. J. Biogeogr. 31:943-957.

VOSS, R., TARIFA, T. \& YESEN, A.E. 2004. An introduction to Marmosops (Marsupialia: Didelphidae), with the description of a new species from Bolivia and notes on the taxonomy and distribution of other bolivian forms. Am. Mus. Novit. 3466:1-40.

VOSS, R., LUNDE, D. \& JANSA, S.A. 2005. On the Contents of Gracilinanus Gardner and Creighton, 1989, with the description of a previously unrecognized clade of small didelphid marsupials. Am. Mus. Novit. 3482:1-34.

WEKSLER, M. \& BONVICINO, C.R. 2005. Taxonomy of pigmy rice rats genus Oligoryzomys Bangs, 1900 (Rodentia, Sigmodontinae) of the Brazilian Cerrado, with description of two new species. Arq. Mus. Nac. 63(1):113-130.

WEKSLER, M., PERCEQUILLO, A.R. \& VOSS, R. 2006. Ten new genera of Oryzomyine Rodents (Cricetidae: Sigmodontinae). Am. Mus. Novit. 3537:1-29.

WILSON, D.E. \& REEDER, D.M. 2005. Mammal species of the world. Johns HopkinsUniversity Press, Baltimore, 2142 p. 


\section{Appendix}

Species recorded, registration number, localities, data and sex determination $(\phi=$ female; $\hat{\sigma}=$ male and $\mathrm{I}=\mathrm{Indeterminate}$ sex $)$ are described below. Specimens captured during this study are indicated by a star (*), those which were karyotyped (Pereira \& Geise 2007) by two stars (**). Acronyms for institutions are: MN = Museu Nacional - Rio de Janeiro; MVZ = Museum of Vertebrate Zoology, University of California, Berkeley; MZUSP = Museu de Zoologia da Universidade de São Paulo; CD = field number of BIOTA/FAPESP. Other prefixes correspond to field numbers of the collector L. Geise (LG).

\section{DIDELPHIMORPHIA}

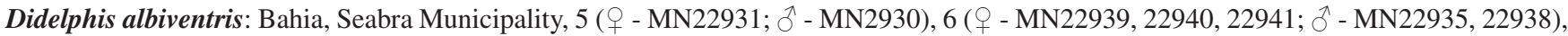

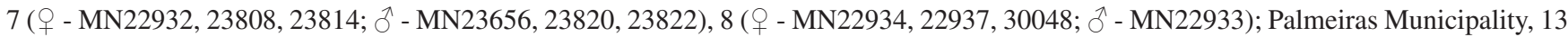
(† - MN22936); Lençóis Municipality, 20 († - MZUSP33826*; đ̊ - CD179*); Andaraí Municipality, 24 (q - MVZ197768).

Gracilinanus agilis: Bahia, Andaraí Municipality, 24 (ð̋ - MVZ197788).

Gracilinanus microtarsus: Bahia, Lençóis Municipality, 23 ( ð̊ - MZUSP33832*); Mucugê Municipality, 26 (૧ - LG409**).

Marmosops incanus: Bahia, Seabra Municipality, 8 († - MN27940); Palmeiras Municipality, 4 († - LG288*, 303*); Lençóis Municipality, 20 ( + - CD190*, 205*; ○ - CD146*, 191*), 23 ( $($ - MZUSP33836*, 33837**, 33839*, 33843*, 33846*, 33847*, 33848*, CD69, 79*, 96*, 97*, 106*, 116*, 118*, 123*, 145*; ô-MZUSP33835*, 33838**, 33840*, 33841*, 33842*, 33844** 33845*, CD77*, 78*, 105*, 107*, 108*, $\left.109^{*}, 113^{*}, 115^{*}, 117^{*}, 119^{*}, 127^{*}, 159^{*}, 160^{*}, 163^{*}, 166^{*}, 182^{*}, 202^{*}\right)$; Andaraí Municipality, 24 (ㅇ - MVZ197781; ð - MVZ197761); Itaetê Municipality, 29 (ㅇ - LG217**).

Marmosa murina: Seabra Municipality, 9 († - MN27941).

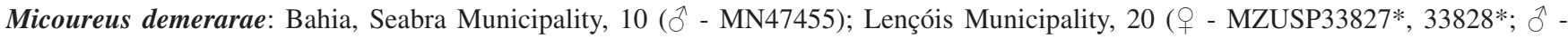
MZUSP33829*, 33830*, 33831*, CD128*); Andaraí Municipality, 24 ( - MVZ197416, 197417, 197420, 197779, 197783, 197784, 197786; o - MVZ197418, 197419, 197646, 197773, 197774, 197775, 197776, 197777, 197780, 197785, 197787).

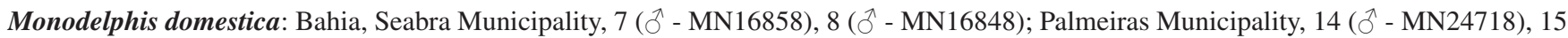
(૧ - MN16418); Lençóis Municipality, 20 ( ̋̂ - MZUSP 33834, CD219*), 23 (૧ - MZUSP33833**); Mucugê Municipality (I - MZUSP28939),

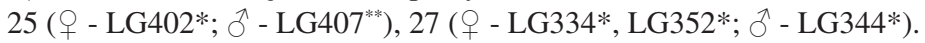

Thylamys karimii: Bahia, Mucugê Municipality, 27 (ð- LG362*).

\section{CINGULATA}

Dasypus novencinctus: Bahia, Lençóis Municipality, 23 (૧ - CD6*, 22*; Љ - CD121*).

Euphractus sexcinctus: Bahia, Lençóis Municipality, 23 ( - MZUSP33825*).

Cabassus taouay: Bahia, Lençóis Municipality, 23 (ð๋ - CD215*).

PILOSA

Tamandua tetradactyla: Bahia, Morro do Chapéu Municipality, 2 (I - MN67898); Abaíra Municipality, 30 (I - MN67817).

\section{PRIMATES}

Callithrix jacchus: Bahia, Lençóis Municipality, 22 (I-LG209).

\section{CARNIVORA}

Cerdocyon thous: Bahia, Morro do Chapéu Municipality, 1 (I - MN44546); Lençóis Municipality, 20 (ð̋ - CD208*), 22 (I - MN67672, đ̂ MN67673), 23 (ð - MZUSP33835*); Aracatu Municipality, 31 (I - MN67674).

Gallictis vittata: Bahia, Morro do Chapéu Municipality, 3 (I - MN67897).

\section{ARTIODACTYLA}

Pecari tajacu: Bahia, Morro do Chapéu Municipality, 2 (I - MN67912).

\section{RODENTIA}

Akodon cursor: Bahia, Lençóis Municipality, 20 ( + - MN69952**, 69958**, 143**; đ - MN69951** 69955**, 69956**, 69957**, CD154*,); 23 (q - MN69939*, 69941*, 69943*, 69944*, 69946*, 69947*, 69948*, 69949*, 69950*, CD95*; đ̊ - MN69938**, 69940**, 69942**, CD69**, $157^{* *}, 164^{* *}$ ); Andaraí Municipality, 24 (I - MVZ197458, 197760). 
Calomys expulsus: Bahia, Seabra Municipality (I - MN13292, 13346, 22625, 22627, 22628, 22633, 22636, 22637, 22638, 22657, 22661, 22665, 22680, 22684, 22686, 22696, 22699, 22700, 22890, 62419, 62420, 62422, 62423, 62428, 62436, 62440, 62446, 62454, 62465); Itaetê

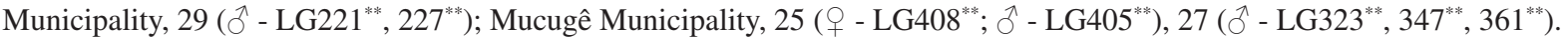

Cerradomys vivoi: Bahia, Lençóis Municipality, 20 (q - MZUSP33823**,134** $135^{* *}, 144^{* *}, 150^{* *}, 168^{* *}, 171^{* *}, 173^{* *}, 180^{* *}, 186^{* *}, 189^{* *}$, $195^{* *}, 198^{* *}, 206^{* *}, 243^{* *}$; o - CD133** $\left.138^{* *}, 140^{* *}, 142^{* *}, 149^{* *}, 151^{* *}, 152^{* *}, 169^{* *}, 170^{* *}, 187^{*}, 197^{*}, 199^{* *}, 200^{* *}, 204^{* *}, 217^{* *}, 240^{* *}, 241^{* *}\right)$,

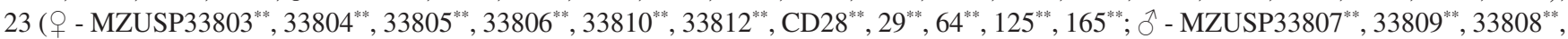
33811**, CD73**, 181**); Andaraí Municipality, 24 (ㅇ - MVZ197541, 197645, 197772; đ̃ - MVZ197540, 19542, 197762, 197765, 197766,

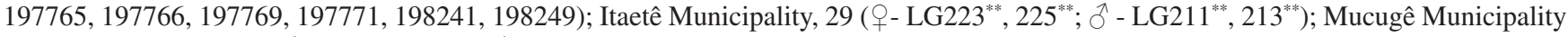

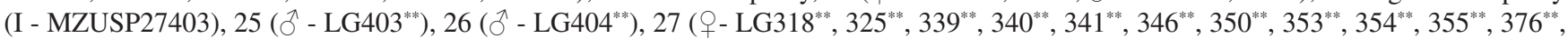
$381^{* *}, 383^{* *}$; ó-LG335 $\left.5^{* *}, 338^{* *}, 348^{* *}, 351^{* *}, 359^{* *}, 365^{* *}, 366^{* *}, 368^{* *}, 369^{* *}, 372^{* *}, 373^{* *}, 380^{* *}, 382^{* *}\right)$.

Necromys lasiurus: Bahia, Palmeiras Municipality (I - MN44167, 44169, 44170), 13 (ㅇ - MN19496, 19499, 19500, 19502, 19503, 19522, 44156; đ̊ - MN19501, 19506, 19514, 19515, 19521, 19523, 19525, 19526, 44160, 44162), 14 (ð - MN44158), 16 (q - MN44157; đ̂ MN44159), 17 (I - MN44161, 44163, 44164, 44165, 44166); Lençóis Municipality, 20 ( - MZUSP33816*; $\overbrace{}^{*}$ - MZUSP33815**), 21 (ㅇ

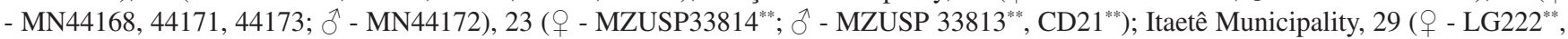

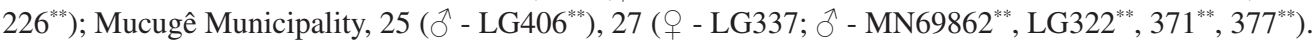

Nectomys squamipes: Bahia, Lençóis Municipality, 20 († - CD192*).

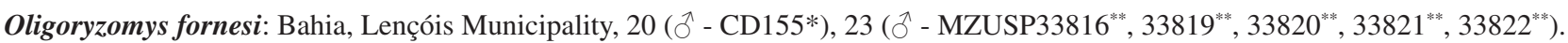

Oligoryzomys nigripes: Bahia, Seabra Municipality (I - MN15960, 15979, 16007, 18282, 18284, 18288, 18291, 18292, 18296, 18299); Lençóis Municipality, 23 ( ̋ - MZUSP33817*); Itaetê Municipality, 29 († - LG212**, LG224**).

Oligoryzomys rupestris: Itaetê Municipality, 29 (ð - LG214**, LG228**).

Pseudoryzomys simplex: Bahia, Palmeiras Municipality (I - MN15086); Mucugê Municipality, 27 (q- LG375*).

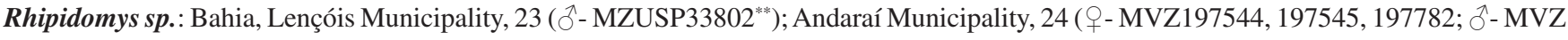
197763, 197764, 197767).

Wiedomys pyhhorhinos: Bahia, Seabra (I - MN18343, 18430, 18433, 18438, 18500, 18503, 18504, 18505, 18510, 18516, 18706, 18707, 18709, 60768, 60772, 60774, 60775, 60778); Palmeiras Municipality (I - MN18751, 60777); Itaetê Municipality, 29 (ふ઼- LG215**).

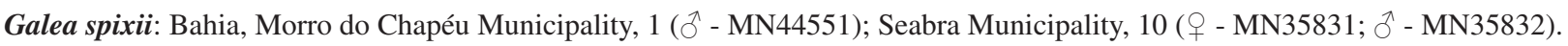

Phyllomys blainvilli: Bahia, Seabra Municipality, 10 (- - MN21627, 21629, 21631, 21632, 21633, 21634, 21640, 21643, 21644, 21645, 21646, 21648, 21649; ठิ- MN21626, 21628, 21630, 21635, 21636, 21637, 21638); Andaraí Municipality, 24 (ô- MVZ197778).

Thrichomys inermis: Bahia, Palmeiras Municipality, 4 ( $9-$ MN70062**, 70068**, 70070**, 70073**, 70074*, 70075**, 70076**, 70079*, 70080*;

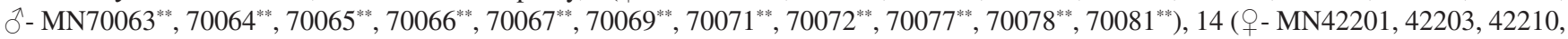
42253, 42255, 42259, 42263, 42269; ô- MN42217, 42223, 42226, 42252, 42254, 42265, 42271, 42280), 15 (I - MZUSP26689, 26690), 16 (ㅇ-MN42204; I - 26687, 26688), 18 (ㅇ- MN14618, 14620, 14622, 22560, 22562, 22563, 22565, 22568, 22572, 42205, 42207, 42208, 42209, 42213, 42214, 42218, 42222, 42244, 42245, 42246, 42248, 42249, 42250, 42251, 42264; đ- MN14621, 14630, 22539, 22561, 22564, 22566, 22567, 22569, 22570, 22571, 42206, 42211, 42212, 42221, 42242, 42243, 42247, 42258), 19 (ㅇ- MN22543, 42196, 42215, 42219, 42220, 42225, 42227, 42228, 42256, 42257, 42260, 42261, 42262, 42270, 42272, 42273, 42274, 42275, 42276, 42277, 42278; đో- MN22540, 22541, 22542, 42216, 42224, 42229, 42266, 42267, 42268, 42279, 42281); Lençóis Municipality, 20 (૧- MZUSP33796*, 33797*, 33798*, 33799*, 33800*, CD220*; §- MZUSP33795*, 33801*, 131*), 23 (ð-MZUSP33794**); Mucugê Municipality (I - MZUSP27387), 27 ( + - MN70086** $70088^{* *}, 70089^{* *}, 70090^{* *}, 70091^{* *}, 70094^{* *}, 70095^{* *}, 70099^{* *}$; 今- MN70082*, 70083*, 70084*, 70085*, 70087**, 70092**, $\left.70093^{* *}, 70096^{* *}, 70097^{* *}, 70098^{* *}, 70100^{* *}\right)$.

Trinomys albispinus: Bahia, Morro do Chapéu Municipality (I - MZUSP28886, 28887, 28888, 28940); Seabra Municipality (I - MN34005, 34006, 34007, 34008, 34009); Andaraí Municipality, 24 (ㅇ- MVZ197571, 197770; §̂- MVZ197570).

Trinomys minor: Bahia, Morro do Chapéu, 2 (ㅇ- MN44544; §ึ- MN44543, 44547); Seabra Municipality, 6 (ㅇ- MN13790, 13792, 13793;

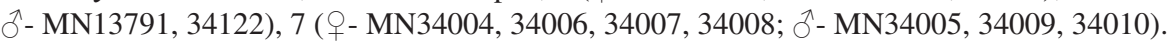

\section{LAGOMORPHA}

Sylvilagus brasiliensis: Bahia, Seabra Municipality, 10 (ㅇ-MN24055, 24056, 24058, 24059, 28581, 28582, 28583$), 11$ (ㅇ- MN24050), 12 (ふ)- MN24052). 